\title{
HORMONAL REGULATION OF MIDGUT DIGESTIVE ENZYME ACTIVITY IN APIS CERANA INDICA (HYMENOPTERA: APIDAE)
}

\author{
M.M. Shinkhede ${ }^{*}$ and D.B. Tembhare ${ }^{2}$ \\ 1Dada Ramchand Bakhru Sindhu Mahavidyalya, Nagpur (M.S.) \\ ${ }^{2}$ Poat Graduate Teaching Department of Zoology, RTM Nagpur University, Nagpur \\ *corresponding author's email: shinkhedemilnd@gmail.com.
}

Communicated: 29.07.20

Revision :09.08.20 \& 29.8.2020

Accepted: 14.09 .2020

Published: 30.09 .2020

\begin{abstract}
:
In insects, there are various digestive processes like enzyme secretion, epithelial tissue regeneration, absorption of nutrients, working of gut musculature and maintenance of gut $\mathrm{pH}$. These all activities are regulated by peptides of insect brain and midgut. Effects of brain and midgut epithelium on secretion of digestive enzymes have been investigated, employing an in vitro method, to ascertain direct action of the gut peptides. The large numbers of neuropeptides localized, isolated and structurally identified from different insect groups highlight the complexity of the neurosecretory system in regulating various physiological processes. During the bioassay experiment, brain extract showed on significant effect while midgut extract elevated significantly the amylase and protease activity. The role of midgut in the regulation of digestive enzyme activity is proved in Apis cerana indica.
\end{abstract}

Key words: - Digestive enzymes, brain and midgut extract, bioassay, Apis cerana indica.

\section{INTRODUCTION:}

Recently, ultrastructural and immunocytochemical studies have revealed various peptides in the neurosecretory cells in the brain and midgut endocrine cells in large number of insects similar to the vertebrate peptide hormones (Schols et al., 1987; Remy and Veliemoniuge, 1988; Montuega et al., 1989; Crim et al., 1992; Schoofs et al., 1993; Zitnan et al., 1993; Lundquist et al., 1994; Muraleedharan et al., 1994; Nijhout, 1994; Veenstra et al., 1995; Lehane, 1998; Lange, 2001; Wang et al., 2001; Neves et al., 2002; Tembhare and Rathee, 2005; Tembhare and Indurkar, 2005; Patankar and Tembhare, 2006).

According to some workers some neuropeptides recognized in the brain and midgut of insects represent sulfakinins, which stimulate digestive enzyme secretion (Schoofs et al., 1990; Fonagy et al., 1992; Predel et al.,
1999; Fuse et al., 1999; Wei et al., 2000; Harshini et al., 2002a, b; Hill and Orchard, 2005). No information is, however, available on the hormonal regulation of digestive enzyme secretion in the Indian honey bee Apis cerana indica. The present work has, therefore, been undertaken on the Indian hive bee Apis cerana indica to analyze effect of brain and midgut extracts on the midgut digestive enzyme activity.

\section{MATEIAL \& METHODS:}

\section{Experimental Design}

In order to investigate effect of brain and midgut extracts the bioassay technique has been used during the present study.

Bioassay apparatus

The bioassay apparatus is glass cylinder, $5 \mathrm{~cm} \mathrm{x}$ $1 \mathrm{~cm}$ diameter open above fitted with a rubber stopper and hypodermic needle was inserted through the stopper at one side for the delivery of oxygen. The midgut preparation was 
suspended with another side of rubber stopper.

The chamber of the bioassay apparatus contained incubation solution. The apparatus was kept in water bath at $37^{\circ} \mathrm{C}$.

\section{Preparation of brain extract}

The brain was dissected out carefully in insect saline. Insect saline containing tissues were boiled for $10 \mathrm{~min}$., to denature the hydrolytic enzymes present in them. It was cooled and homogenized in a glass homogenizer by hand. The homogenate was centrifuged at $10000 \mathrm{rpm}$ for $10 \mathrm{~min}$. The supernatant obtained was used as incubation solution in the bioassay. The concentration of the extract was adjusted to 2brain/ $10 \mathrm{ml}$ insect saline.

\section{Preparation of midgut extract}

Alimentary canal was dissected out in insect saline. The midgut was cut behind the foregut and posteriorly just above the hindgut. The contents of the midgut were removed by injecting the insect saline into the open midgut tube and contents were flushed out. The epithelial tissue was washed in insect saline and transferred to fresh saline. The extract of the midgut epithelia was prepared as described above for the brain extract. The homogenate having a concentration equivalent to two midgut epithelia / $10 \mathrm{ml}$ saline was bioassayed for its effect on in vitro digestive enzyme secretion in preparation of the midgut.

Preparation of midgut for bioassay experiment Dissected midgut was taken out and washed in insect saline. Injecting saline into lumen of gut with a syringe and washed in several changes of insect saline flushed out the contents. The two ends of the open were legated with silken thread. The legated empty tubes thus prepared were used in the bioassay.

\section{Bioassay experimental procedure}

The midgut preparation was incubated with $2 \mathrm{ml}$ of the incubation solution (midgut epithelial extract or brain extract) in the bioassay apparatus for $30 \mathrm{~min}$., bubbling a gentle stream of oxygen. After incubation, the midgut preparation was taken out and washed in insect saline. The gut was opened and content were collected in $0.5 \mathrm{ml}$ distilled water by washing, for estimation of protease and amylase activity.

In control experiments, legated midgut tubes were incubated in insect saline.

\section{RESULTS AND DISCUSSION:}

Some bioassay experiments were conducted to study the effect of midgut extract (MGE) and brain extract $(\mathrm{BE})$ on the midgut amylase and protease activity in the honeybee, Apis cerana indica and the results are given below-

\section{EFFECT OF MIDGUT EXTRACT}

\section{Amylase activity}

The midgut amylase activity is measured about $0.64 \pm 0.006, \quad 0.67 \pm 0.011, \quad 0.71 \pm 0.009$ and $0.73 \pm 0.012 \mathrm{mg}$ glucose/ midgut/ min. after incubation in midgut extract (MGE), while, it was observed about 0.58 $\pm 0.009,0.58 \pm 0.008$, $0.58 \pm 0.0037$ and $0.57 \pm 0.0081 \mathrm{mg}$ glucose/ midgut/ min. in the control condition after 15, 30, 45 and $60 \mathrm{~min}$. intervals, respectively. The present study shows that the amylase activity after incubation in MGE increases significantly $(\mathrm{P}<0.0001)$ in comparison to that in the control condition after 60 min. (Fig.1).

\section{Protease activity}

The midgut protease activity is measured about $0.83 \pm 0.010, \quad 0.86 \pm 0.0031, \quad 0.87 \pm 0.007$ and $0.80 \pm 0.005 \mathrm{mg}$ protein/ midgut/ min. after incubation in MGE, while it was noticed about $0.78 \pm 0.006, \quad 0.81 \pm 0.008, \quad 0.82 \pm 0.007$ and $0.74 \pm 0.003 \mathrm{mg}$ protein/ midgut/ $\mathrm{min}$. in the 
I J R B A T, Issue (VIII), Vol. III, Sept 2020: 178-185

A Double-Blind Peer Reviewed \& Refereed Journal

control condition after 15, 30, 45 and $60 \mathrm{~min}$. intervals respectively. It suggests a significant increase in protease activity $(\mathrm{P}<0.0001)$ in comparison to that in the control condition after 60 min. (Fig.2).

\section{EFFECT OF BRAIN EXTRACT}

\section{Amylase}

The midgut amylase activity is measured $0.68 \pm 0.020, \quad 0.71 \pm 0.008, \quad 0.76 \pm 0.008$ and $0.81 \pm 0.013 \mathrm{mg}$ glucose/ midgut/ min. after incubation in brain extract $(\mathrm{BE})$, while it was observed about $0.63 \pm 0.014, \quad 0.64 \pm 0.018$, $0.74 \pm 0.014$ and $0.75 \pm 0.014 \mathrm{mg}$ glucose/ midgut/ min. in the control condition after 15, 30, 45 and $60 \mathrm{~min}$. intervals, respectively. The present study shows that the amylase activity after incubation in (BE) increases slightly (nonsignificant), in all intervals from that in control condition (Fig.3).

\section{Protease activity}

The midgut protease activity is measured about $0.54 \pm 0.012, \quad 0.49 \pm 0.011, \quad 0.58 \pm 0.019$ and $0.51 \pm 0.015 \mathrm{mg}$ protein/ midgut/ min. after incubation in $\mathrm{BE}$, while it is noticed about $0.45 \pm 0.016, \quad 0.42 \pm 0.011, \quad 0.48 \pm 0.013$ and $0.40 \pm 0.009 \mathrm{mg}$ protein/ midgut/ min. in control condition after 15, 30, 45 and 60 min. intervals respectively. The present study shows that the protease activity after incubation in $\mathrm{BE}$ increases slightly (non-significant) in comparison to that in control condition (Fig.4).

The presence of vertebrate gastro-intestinal hormones in the brain and midgut in various insects has been reported by some workers (Crim et al., 1992; Yi et al., 1992; Muraleedharan et al., 1994; Brown et al., 1999; Lange, 2001; Neves et al., 2002; Surg et al., 2002) but the functional significance of these hormones in the insects is still obscure.
e-ISSN 2347 - 517X

Original Article
Chapman (1998) moreover, supported the view of some earlier workers that these substances may regulate the synthesis and release of the digestive enzymes secreted by the columnar epithelial cells of the midgut and play a key role in the physiology of digestion in insects. The peptides of insect brain and midgut are suggested to have important regulatory role in digestive processes like, enzyme secretion, epithelial tissue regeneration, absorption of nutrients, working of gut musculature and maintenance of gut $\mathrm{pH}$ (Prabhu and Sreekumar, 1994; Muraleedharan, 1995; Sunitha et al., 1999). Effects of brain and midgut epithelium on secretion of digestive enzymes have been investigated in the larvae of Opisina arenosella, employing an in vitro method, to ascertain direct action of the gut peptides (Harshini, 1999). Recently, it is reported that an unidentified brain/ midgut peptides stimulate the release of amylase from the midgut tissue in the larvae of Opisina arenosella (Harshini et al., 2003), Antheraea mylitta (Tembhare and Rathee, 2005), Cybister tripunctatus (Tembhare and Indurkar, 2005) and Tramia virginia (Patankar and Tembhare, 2006) respectively.

In the perview of above said concept, the present study was undertaken to search effect of brain and midgut hormones on the midgut digestive enzyme activity in Apis cerana indica through a bioassay experiment. During the present study brain extract showed no significant effect while the midgut extract elevated significantly the amylase and protease activity. The stimulatory effect of the midgut extract on the digestive enzyme activity was reported by some earlier workers in various insects (Raman and Murleedharan, 1987; Sreekumar and Prabhu, 1988b; Montuega et al., 
I J R B A T, Issue (VIII), Vol. III, Sept 2020: 178-185

A Double-Blind Peer Reviewed \& Refereed Journal

1989; Veenestra et al., 1995; Wei et al., 2002 Harshini et al., 2003; Tembhare and Rathee, 2005).

Although the brain extract caused significant increase in midgut digestive enzyme activity in Calliphora erythrocephala (Thomsen and Moller, 1959; Thomsen, 1966; Holter and Thomsen, 1971) Tenebrio molitor (Mordue, 1967; Invanicovic, et al., 1975), Glossina morsitans (Langley, 1967), Morimus fenereus (Invanicovic, et al., 1978) and Dysdercus cingulatus (Muraleedharan and Prabhu, 1979), no significant changes were found in the concentration of midgut amylase and protease after incubation in the brain extract suggesting that the brain neurohormones are perhaps, not involved in the regulation of midgut digestive enzyme activity in Apis cerana indica.

From the present studies, the role of midgut in the regulation of digestive enzyme activity is proved and it may occur due to the involvement of midgut containing vertebrate gastro-intestinal hormones such as gastrin and CCK or alike hormonal substances. It is now well established that the midgut acts as an independent endocrine organ in insects (Chapman, 1998). Various hormonal substances have been demonstrated in the midgut endocrine cells in insects, which profoundly act through paracrine mode (Fujita, 1981) and stimulate the columnar cells promoting synthesis and release of the midgut digestive enzymes (Brown et al., 1986; De Loof, 1987; Sreekumar and Prabhu, 1988b; Montuega et al., 1989; Veenestra et al., 1995; Muraleedharan, 1995; Chapman, 1998). It is equally true in the honeybee Apis cerana indica also. The bioassay experiment has shown the significant effect of brain extract and midgut extract on amylase and protease activity. The role of midgut in the regulation of digestive enzyme activity is proved in Apis cerana indica.

\section{CONCLUSION:}

From the present studies, the role of midgut in the regulation of digestive enzyme activity is proved and it may occur due to the involvement of midgut containing vertebrate gastro-intestinal hormones such as gastrin and CCK or alike hormonal substances. The bioassay experiment has shown the significant effect of brain extract and midgut extract on amylase and protease activity. The role of midgut in the regulation of digestive enzyme activity is proved in Apis cerana indica.

\section{REFERENCES:}

BROWN, M. R., CRIM, J. W., AND LEA, A.O. (1986). Pancreatic polypeptide-like immunoreacivity of endocrine cells in the midgut of mosquito. Tissue and Cell 18: 414-428.

BROWN, M.R., CRIM, J.W., ARATA, R.C., CAI, H.N., CHUN, C. AND SHEN, P. (1999). Identification of the Drosophilla braingut peptide related to the neuropeptide Y family. Peptides. 20: 1035-1042.

CHAPMAN, R.F. (1998). Endocrine system. A textbook of Insects structure and function IV (Cambridge Uni. Press).

CRIM, J.W., JENKINS, A.C. AND BROWN, M.R. (1992). A mosquito neuropeptide in moth larva (Helicoverpa zea) related to FMRF amide immunoractivity. Tissue Cell 24: 537-545.

DE LOOF, A. (1987). The impact of discovery of vertebrate type steroids and peptide hormone-like substances in insects. 
I J R B A T, Issue (VIII), Vol. III, Sept 2020: 178-185

A Double-Blind Peer Reviewed \& Refereed Journal

Entomologia Experimentaus et Applicata 45: 105-113.

FONAGY, AL., SCHOOFS, L., PROOST, P., VAN DAMME, J., AND DE LOOF, A. (1992). Isolation and primary structure of two sulfakinin-like peptides from the fleshfly, Neovellieeria bullata. Comp. Biochem. Physiol. (C) 103: 135-142.

FUSE, M, ZHANG, J.R., PATRIDGE, E., NACHMAN, R.J., ORCHARD, I., BENDENA, W.G. AND TOBE, S.S. (1999). Effects of an allatostatin and a myosuppressin on midgut carbohydrate enzyme activity in the cockroach, Diploptera punctata Peptides 2: 12851293.

FUJITA, T., YUI, R., IWANAGA, T., NISHIITSUTSUJI-UWO, J., ENDO, Y. AND YANAIHARA, N. (1981). Evolutionary aspects of "Brain-gut peptides": An immuno-histochemical study. Peptides. 2 (Suppl. 2): 123.

HARSHINI, S. (1999). Ph.D. Thesis, University of Kerala.

HARSHINI, S., NACHMANN, R.J., SREEKUMAR, S. (2002a). Inhibition of digestion enzyme release by neuropeptide in the larvae of Opisina arenocella (Lepidoptera: cryptophasidae) Comparative Biochemistry and Physiology B 132/2: 353-358.

HARSHINI, S., NACHMANN, R.J., SREEKUMAR, S. (2002b). In-vitro release of digestive enzymes by FMRF-amide related neuropeptide and analogous in the lepidopteran insects Opisina arenocella (Walk) Peptides 23/10: 1759-1763.

HARSHINI, S., RESHMI, V. AND SREEKUMAR, S. (2003). A brain peptide stimulate
e-ISSN 2347 - 517X release of amylase from the midgut tissue of larvae of Opisina arenosella Walk. (Lepidoptera: Cryptophasidae). In: Neuropeptide.

HILL, S. R. AND ORCHARD, I. (2005). In vitro analysis of the digestive enzymes amylase and alphaglucosidase in the midguts of Locusta migratoria. Peptides 22: 229-234.

HOLTER, K. AND THOMSEN, E. (1971). Esterase activity of the posterior midgut of the female blowfly, Calliphora erythrocephala. J. Insect Physiol. 17:1471- 1478 .

IVANOVIC, J., JANKOVIC-ALADINI, M. AND MILANOVIC, M. (1975). Effect of constant temperature on survival rate, neurosecretion and endocrine cells and digestive enzymes in Morimus funereus Comp. Biochem. Physiol. 50A: 125-130.

IVANOVIC, J.T., JANKOVIC-ALADINI, M.T., STANIC, V., MILANOVIZ, M.P. AND NENADORIC, V. (1978). The midgut of coleopteran larvae, the possible target oron for the action of neurohormones. In: Neurosecretion and Neuroendocrine Activity: Evolution, structure and Function (W. Bargman, A. Okashe, A. Polenov and B. Scharrer, eds) pp. 373376, Springer Verlag, Berlin.

LANGE, A.B. (2001). Feeding state influence the contact of FMRF amide and tachykinin related peptides in endocrine- like cells of the midgut of Locusta migretoria: Peptides 22 (2): 229-34.

LEHANE, M. J. (1998). The midgut. In: F. W. Harrison and M. Locke, [Eds], Microscopic anatomy of invertebrate, 11B, pp. 725-746, Wiley-Liss, New York. 
I J R B A T, Issue (VIII), Vol. III, Sept 2020: 178-185

A Double-Blind Peer Reviewed \& Refereed Journal



e-ISSN 2347 - 517X

Original Article
LUNDQUIST, C. T., CLOTENS, F. L., HOLMAN, G. M., RIEHM, J. P., BONKALE, W. AND NASSEL, D. R. (1994). Locustatachykinin immunoreactivity in the blowfly central nervous system and intestine. J. Comp. Neurol., 341: 225240.

MONTUENGA, L.M., BARRENE CHEA, M.A., SESMA, P., LOPEZ, J. AND VASQUEZ, J.J. (1989). Ultrastructure and immunocytochemistry of endocrine cells in the midgut of the desert locust, Schistocerca gregaria (Forskal). Cell and Tissue Research 258: 577-583.

MORDUE, W. (1967). The influence of feeding upon the activity of the neuroendocrine system during oocyte growth in Tenebrio molitor. General and Comparative Endocrinology 9: 406-415.

MURALEEDHARAN, D. AND PRABHU, V.K.K. (1979a). Effect of quality food on midgut Invertase activity in red cotton bug, Dysdercus cingulatus Fabr. Indian J. Expt. Biol. 17: 1262-1263.

MURALEEDHARAN, D. AND PRABHU, V.K.K. (1979b). Role of median neurosecretory cells in the secretion of protease and Invertase in red cotton bug, Dysdercus cingulatus. J. Insect Physiol. 25: 237 240.

MURALEEDHARAN, D. (1995). Endocrinology of midgut. In : Recent advances in insect endocrine research. (Eds. D. Muraleedharan and Mariamma Jacob) Association for advancement of Entomology, Trivandrum 99-115.

MURALEEDHARAN, D., SMID, H.M. AND SCHOONEVELD, H. (1994). Midgut of the Colorado beetle as a source of peptides with myotropic function. Proc. Exper. Appl. Entomol. 5:55-60.

NEVES, C.A., BHEING, L.L., SERRAO, J.E., GITIRANA, L.B. (2002). FMRF- amide like midgut endocrine cells during the metamorphosis in Melipona quadsifasciata anthidioides (Hymenoptera: Apidae) In: Micron. 33 (5): 453-60.

NIJHOUT, H. F. (1994). Insect hormones. Princeton Uni. Press.

PATANKAR, N.V. AND TEMBHARE, D.B. (2006). Immunocytochemical demonstration of some vertebrate peptide hormone-like substances in the midgut endocrine cells in Tramea virginia (Rambur) (Anisoptera: Libellulidae). Odonatologica 35(2): 151-158.

PREDEL, R., BRANDT, W., KELLNER, R., RAPUS, J., NACHMAN, R. J., AND GADE, G. (1999). Post-transitional modifications of the insect sulfakinins: sulfation, pyroglutamate-formation and O-methylation of glutamic acid. Eur. J. Biochem. 263: 552-560.

PRABHU, V.K.K AND SREEKUMAR, S. (1994). Endocrine regulation of feeding and digestion in insects. In: Perspectives $n$ Entomological Research, (Eds. P. Agrawal, Scientific Publishers, Jodhpur). 117-135.

RAMAN, S. AND MURALEEDHARAN, V. (1989). Hormone modulation of secretion and secretory rhythms of some carbohydrates in semilooper calterpillar, Achaea janata L. (Lepidoptera: Noctuidae). Natri. Ecol. Ins. Env. 107115. 
I J R B A T, Issue (VIII), Vol. III, Sept 2020: 178-185

A Double-Blind Peer Reviewed \& Refereed Journal
OPEN ACCESS

e-ISSN $2347-517 X$

Original Article
REMY, C. AND VIELLEMARINGE, J. (1988). Immunocytology of insect peptides and amines. In: Neurohormones in invertebrates, (Eds. Thomdyke, M.C. and Gold. Sworthy, G.J.) pp. 43-75, Cambridge Univ. Press, Cambridge.

SCHOLS, D., VERTAERT, P., HUYBRECHTS, R., VAUDRY, H.Y., JEGOU, S.O. AND DEDR LOOF, A. (1987). Immunocytochemical demonstrations of pro-opiomelanocortin and opiod-related substances and CRFlike peptide in the gut of the American cockroach, Periplaneta americana L. Histochemistry 86: 345-357.

SCHOOFS, L., HOLMAN, G. M., HAYES, T. K., KOCHANSKY, J. P., NACHMAN, R. J., A. AND DE LOOF (1990). Locustatachykinin III and IV: two additional insect neuropeptides with homology to peptides of the vertebrate tachykinin family. Regulatory Peptides 31(3): 199-212.

SCOOFS, L., VAN DEN BROECK, J. AND DE LOOF (1993). The myotrophic peptides of Locusta migretoria: Structures, distribution, functions and receptors. Insect Biochem. Molec. Biol. 23: 859881.

SREEKUMAR, S. AND PRABHU, V.K.K. (1988b). Probable endocrine role of midgut tissue is stimulation of digestive-enzyme secretion Oryctes rhinocerous (Coleoptera: Scarabeidae). Proc. Indian Acad. Sci. (Anim. Sci.) 97: 73-78.

SUNITHA, V.B., REENA, T., HARSHINI, S. AND SREEKUMAR, S. (1999). Is gut $\mathrm{pH}$ regulated by midgut endocrine system? Ind. J. Exp. Biol. 37: 423- 426.
SURG, DONG KYUNG, CHAI HYEOCK AND BANG HEE LEE (2002). Localization of allatostatin-producing cells in larval gut of the potato worm Agrius Convolvuli, In: Journal of Entomology, 32 (4): 225-259.

TEMBHARE, D.B. AND RATHEE, S.D. (2005). Immunocytochemical localization of some vertebrate peptide hormones in the midgut endocrine cells and effect of midgut extract on digestive enzyme activity in the tropical Tasar silkworm, Antraea mylitta (Drury) (Lepidoptera: Saturniidae). Int. J. Wild Silkmoth and Silk, 10:1-8.

TEMBHARE, D.B., AND INDURKAR, U.S. (2005). Immunocytochemical localization of vertebrate gastro-intestinal hormonelike substances and their role in the midgut digestive enzyme activity in Cybister tripunctatus O1. (Coleoptera: Dytiscidae). Entomon. 30(4): 279-288.

THOMSEN, E. AND MOLLER, L. (1959). Neurosecretion and intestinal proteinase activity in an insect, Calliphore erythrocephala Meig. Nature 183: 14011402 .

THOMSEN, E. (1966). Esterase in the cells of the hind-midgut of calliphora female and its possible dependence on the medial neurosecretory cells of the brain. Z., Zeliforsch. 75: 281-300.

VEENESTRA, J. A., LAU, G.W., AGRICOLA, H.J. AND PETZEL, D.H. (1995). Immunohostological localization regulatory peptides in the midgut of the female mosquito Aedes aegypti. Histochemistry and Cell Biology, 104: 337-347. 
WANG, P., J. T. CONRAD AND M. SHAHABUDDIN (2001). Localization of midgut-specific protein antigens from Aedes aegypti (Diptera: Culicidae) using monoclonal antibodies. J. Med. Ent. 38: 223-230.

WEI, Z., BAGGERMAN, G., NACHMAN, R., GOLDWORTHY, G., VERHAERT, P., DE LOOF, A. AND SCHOOFS, L. (2000). Sulfakinins reduce food intake in the desert locust, Schistocerca gregaria. J. Insect Physiol. 46: 1259-1265.

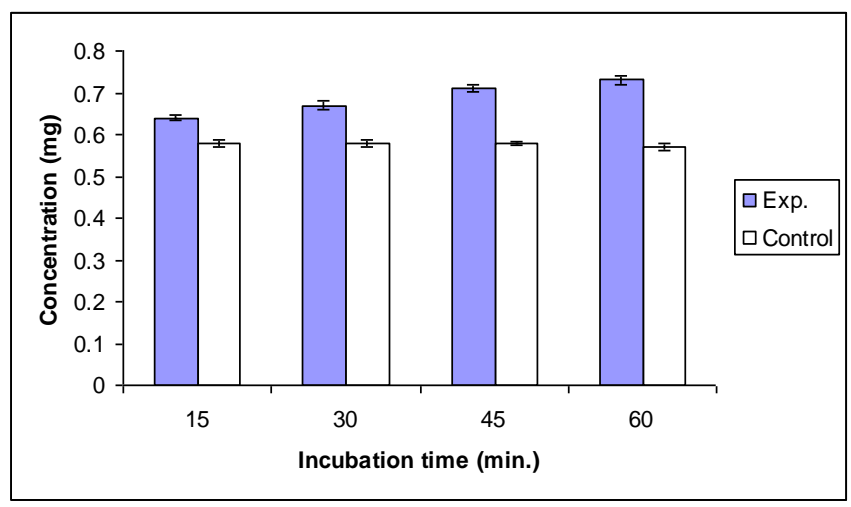

Fig. 1 Effect of MGE on amylase activity

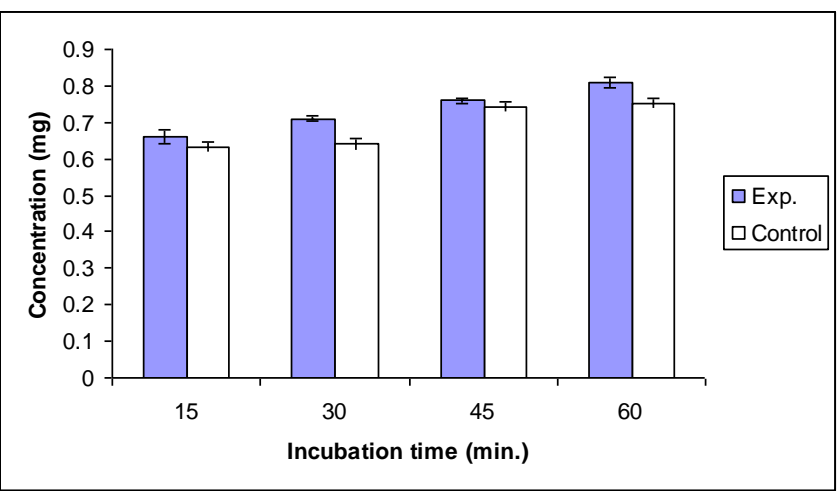

Fig. 3 Effect of BE on amylase activity
YI, S.Y., TIRY, L. AND DE GHHEELA, D. (1992). Presence of myotropins in larval midgut extracts of lepidopteran insects: Manduca sexta, Agrotic segetium and spodoptea exempta. J. Insect Physiol. 38: 1023-1032.

ZITNAN, D., SAUMAN, I. AND SEHNAL, F. (1993). Peptidergic innervation and endocrine cells in insect gut. Arch. Insect Biochem. Physiol. 22: 113-132.



Fig. 2 Effect of MGE on protease activity

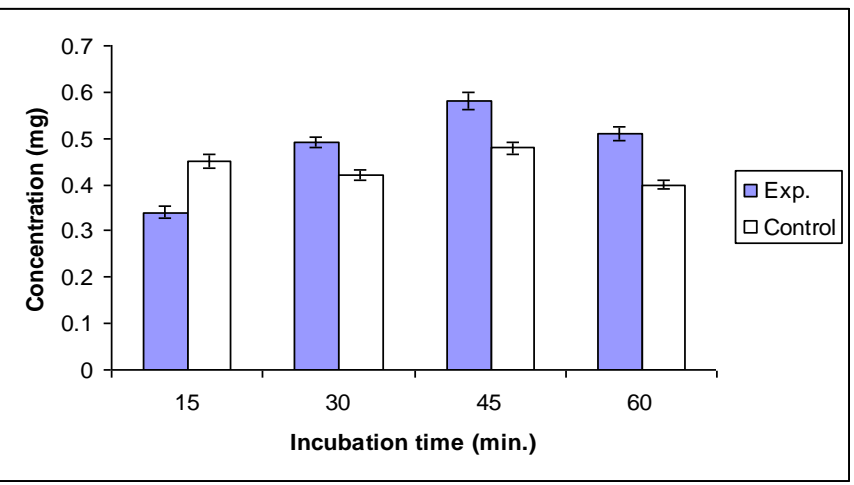

Fig. 4 Effect of BE on protease activity 